\title{
VARIATION IN THE LEVEL OF ACTIVITY ACROSS THE STAGES OF THE ENTREPRENEURIAL STARTUP PROCESS-EVIDENCE FROM 35 COUNTRIES
}

\author{
VARIACIÓN EN EL NIVEL DE ACTIVIDAD A TRAVÉS \\ DE LAS ETAPAS DE INICIACIÓN EMPRESARIAL. \\ EVIDENCIA DE 35 PAÍSES
}

\author{
Pia Arenius* \\ STEFAN EHRSTEDT**
}

\begin{abstract}
Alrich and Martinez (2001) pointed out that in "entrepreneurship many are called, but few are chosen". Many entrepreneurs try seriously to create a lasting organization, but most of them do not pass through the three stages of the entrepreneurial startup process. There is scarce research exploring the entrepreneurial startup process, particularly studying across countries the prevalence of individuals in the different stages. This paper uses data collected across 35 countries participating in the 2005 Global Entrepreneurship Monitor (GEM) study and we examine whether individual-level factors and national culture are related to the ratio of nascent entrepreneurs to potential entrepreneurs, and to the ratio of baby business owners to potential entrepreneurs. Our results show that there is significant variation across countries in how many individuals are active in the different stages of the entrepreneurial startup process. Our results also indicate that gender and age are related to a high ratio of nascent entrepreneurs to potential entrepreneurs.
\end{abstract}

Key words: Startup process, stage prevalence rates, cross country comparison.

\section{Resumen}

Alrich y Martínez (2001) señalan que "a emprender muchos son llamados, pero pocos son elegidos". Muchos emprendedores intentan crear organizaciones que perduren, pero la mayoría de ellos no logran superar las tres etapas del proceso emprendedor. Existe muy poca investigación que examina el éxito del proceso emprendedor, sobre todo estudios que midan estas variaciones entre las etapas

* Turku School of Economics, Pori Unit. PO Box 170, 28101 Pori, Finland. Tel. +358 50 386 2780. E-mail: pia.arenius@tse.fi

** Turku School of Economics, Pan-European Institute. Rehtorinpellonkatu 320500 Turku, Finland. Tel. +358 24814 522. E-mail: stefan.ehrstedt@tse.fi 
y que compararen entre distintos países. Este trabajo utiliza los datos de 35 países que participan en el Global Entrepreneurship Monitor (GEM) del año 2005 y examinamos los factores tanto individuales como de la cultura nacional que están relacionados con los ratios entre los emprendedores potenciales y los nacientes y entre los potenciales y los nuevos empresarios. Nuestros resultados muestran que hay variaciones significativas entre las fases iniciales del proceso emprendedor y los países. Nuestros resultados indican que el género y la edad son variables explicativas, sobre todo para la primera transición de potencial a emprendedor naciente.

Palabras clave: Proceso emprendedor, indicadores de etapas, comparación entre países.

JEL Classification: L26, M16.

\section{INTRODUCTION}

Creation of a new venture is the fundamental entrepreneurial achievement. According to the Statistics of U.S. Businesses, more than 8.7 million new firms have been created in the U.S. between 1989 and 2004; an average of more than 580000 annually. Behind this achievement are a large number of entrepreneurs, who despite their intentions, did not succeed in creating a lasting organization. As Aldrich and Martínez (2001) point out 'In entrepreneurship, as in the biblical history, many are called but few are chosen' (p. 41). In their study of the entrepreneurial startup process, Carter et al. (1996) found that 18 months after initial interview, approximately one half of the respondents had initiated a business by the time of the follow-up interview, over $30 \%$ were still engaged in activities to start a new business, and $20 \%$ had given up on their efforts to start a new business. Past research has been, for the most part, interested in explaining entrepreneurial intentions or looked at those who have succeeded in creating a new business. There are less studies on the entrepreneurial startup process and the persistence of entrepreneurs.

The evolutionary theory of entrepreneurship studies the creation of new organizational structures (variation), the way in which entrepreneurs modify their ventures (adaptation), the conditions under which such organizational arrangements lead to success and survival (selection) and the way in which successful arrangements tend to be imitated and perpetuated by other entrepreneurs (retention) (Aldrich and Martínez, 2001). According to Aldrich and Martínez (2001) the most important contribution of the evolutionary theory of the firm is the recognition of 'nascent entrepreneurs'. Nascent entrepreneurs are individuals who seriously intent to start a business and whose efforts may or may not culminate in the birth of a new firm. In evolutionary terms, nascent entrepreneurs are a major source of organizational variation, beginning with their intentions and continuing through their activities oriented toward a realized founding (Aldrich and Martínez, 2001, p. 42).

The evolutionary theory of entrepreneurship has studied the stages of the entrepreneurial process as well as the transitions between the stages (e.g., Reynolds and White, 1997; Reynolds et al. 2004). The literature reports on the 
four stages of the entrepreneurial startup process (Reynolds and White, 1997; Reynolds et al., 2004). The first stage of the entrepreneurial startup process involves the population of all individuals -all those involved in the labor force and those who are employees of existing businesses. Some of these individuals decide to pursue a new business startup. This is the first transition point of the entrepreneurial startup process called 'conception'. Conception is followed by the gestation stage, during which individuals engage in action aimed at starting a firm. Individuals in the gestation phase are called nascent entrepreneurs. If the individual's activities become a new firm, the second transition point in the entrepreneurial startup model is 'birth'. If the birth of a new firm occurs, then the new business is in its infancy stage. Entrepreneurs in the infant stage are called 'baby business owners'. If the infant firm survives, it will enter the adolescence stage, in which it is considered to be an established firm.

Building on the work of Reynolds and his colleagues, Bosma and Schutjens (2007) split the individuals of the first stage into two groups: those individuals who perceive themselves as having the necessary entrepreneurial skills and perceiving entrepreneurial opportunities but who are not entrepreneurially active in any way, and those who do not perceive to have the necessary skills (Bosma and Schutjens, 2007). The first group of individuals is particularly interesting, because one can expect that they show a higher likelihood of deciding to pursue a new business startup. Previous research using GEM data has in fact shown that those who perceive themselves as possessing the necessary skills are several times more likely to be nascent entrepreneurs than those who do not believe to have the necessary skills (Arenius and Minniti, 2005). The individuals perceiving opportunities and having the necessary skills are called potential entrepreneurs in this paper.

The contribution of the literature regarding the entrepreneurial startup process helps us to understand how new firms come into existence and why particular entrepreneurial efforts succeed, while other attempts fail (Reynolds et al., 2004). The transition points of conception and birth are particularly interesting. Entrepreneur passing these transition points persist despite the limitless pitfall of the entrepreneurial startup process and move forward in the startup process. The objective of the present paper is to examine whether individual-level factors and national culture are related to the ratio of nascent entrepreneurs to potential entrepreneurs, and to the ratio of baby business owners to potential entrepreneurs. We know little about the entrepreneurial startup process, particularly of the very early stages of the process and looking at the variation across countries. We will use data collected across 35 countries participating in the 2005 Global Entrepreneurship Monitor (GEM) study. Our dependent variables are two indicators created from the GEM data. Our first dependent variable is the ratio of baby business owners to nascent entrepreneurs. This is an indication of how many of those engaged in startup activities are likely to create viable ventures. Our second dependent variable is ratio of nascent entrepreneur to potential entrepreneur. This is an indication of the likelihood of those having the necessary skills and perceiving entrepreneurial opportunities, actually engaging in actions aiming at the creation of a new venture.

The paper contributes to the evolutionary theory of entrepreneurship by increasing our understanding of the relationship between the different stages of the entrepreneurial startup process. This is done analyzing the transitions 
between the stages of the entrepreneurial startup process. The paper is organized as follows. Section 2 outlines the theoretical basis of the research. In line with previous research, we examine environmental characteristics, namely country and culture, and combine them with individual level factors including age, education and gender. Section 3 is a description of the data used in this study and section 4 reports on the results of the study. Section 5 offers some conclusions.

\section{Theoretical BACKground}

\subsection{Cultural factors}

Prior research has established that nationality has a significant impact on the entrepreneurial preference (e.g., Grilo and Irigoyen, 2006; Blanchflower et al., 2001). However, the existing empirical research on the persistence in the entrepreneurial startup process has used data from single countries, e.g., Parker and Belghitar (2006) use the Panel Study of Entrepreneurship (PSED) data of US, Henley (2007) use the British Household Survey Data, Rotefoss and Kolvereid (2005), Kolvereid and Isaksen (2006) and Alsos and Kolvereid (1999) use data from Norway. The research has overlooked the relationship between culture and persistence in the entrepreneurial startup process.

A whole stream of research has emphasized the deep-rooted and mostly unconscious cultural characteristics of a society as being important factors influencing entrepreneurship (e.g., Inglehart and Baker 2000). Several studies have been conducted examining the relationship of cultural factors and entrepreneurship (e.g., Hayton et al., 2002). Noorderhaven et al. (2004) argue that dissatisfaction at the level of societies has a positive influence on self-employment levels. Wennekers et al. (2007) find a positive direct influence of uncertainty avoidance in business ownership rates for data from earlier decades which had faded by the $21^{\text {st }}$ century. Uhlaner and Thurik (2007) study the influence of post materialistic values on entrepreneurship and found that countries with less materialistic values tend to have lower total entrepreneurial activity as a proportion of the adult population.

Geert Hofstede's four original cultural dimensions are by far the most frequently used cultural explanatory variables for entrepreneurial activity (Hayton et al., 2002). Hofstede's dimensions are as follows: 'individualism-collectivism' expresses the cultural value a given society puts on the individual or, alternatively, on the group. 'Power distance' refers to a society's tolerance for human inequality. 'Masculinity-femininity' reflects a society's emphasis on values which are considered masculine or male, or alternatively feminine or female. For instance, competitiveness and ambition have traditionally been attributed to men, and interpersonal relations and caring have traditionally been attributed to women. Finally, 'uncertainty avoidance' expresses a society's tolerance for an unknown future (Hofstede, 2001).

Most of all 'individualism', as well as 'masculinity' and 'power distance', have been used as explaining factors for entrepreneurship. Shane (1992) examines the relationship between Hofstede's dimensions and national innovation rates and found that 'individualism' is positively and 'power distance' negatively associated with national rates of innovation. Lee and Peterson (2000), in line 
with Shane, suggest that a culture that is, among other things, low on 'power distance', weak in 'uncertainty avoidance', 'masculine' and 'individualistic' in nature will engender strong entrepreneurial orientation. McGrath et al. (1992) conduct a comparison of entrepreneurs and non-entrepreneurs in 13 countries concluding that entrepreneurs are higher in 'power distance', 'individualism' and 'masculinity' and lower in 'uncertainty avoidance'

However, there are other schools of thought as well. Tiessen (1997) argue that both individualism and collectivism can contribute to entrepreneurship, which would explain the recent entrepreneurial success of collectivist societies like China. Mueller and Thomas (2000) conclude that a culture high on 'individualism' is supportive of entrepreneurship but unlike Sang and Peterson, they concluded that strong 'uncertainty avoidance' is supportive of entrepreneurship. Levie and Hunt (2004) study culture as an explaining factor for differences in new business activity across nations. They found some evidence linking the level of a country's new business activities to positive new business-activity related beliefs in a country. However, they found only weak evidence for a direct association between cultural values and new business activity.

In the present paper we expect that the relationship between culture and the entrepreneurial startup process is similar to that of culture and entrepreneurial activity. Hence our first hypothesis reads as follows:

Hypothesis 1: At the country level, individualism and masculinity are positively and power distance negatively related to a) the ratio of nascent entrepreneurs to potential entrepreneurs and $b$ ) the ratio of baby business owners to nascent entrepreneurs.

\subsection{Age}

At the individual-level age is generally related with the preference for selfemployment and the actual entry into self-employment. Grilo and Irigoyen (2006) and Henley (2007) find that the likelihood of preferring self-employment decreases with age. For example, Henley (2007) report that aspiring entrepreneurs are on average 3 years younger than non-aspirers. At the same time the likelihood of being self-employed increases with age (Grilo and Irigoyen, 2006). Grilo and Irigoyen (2006) offer a dynamic perspective to explain this discrepancy. Young cohorts show a high level of entrepreneurial aspirations, but only a few of them actually become entrepreneurs because of limited opportunities. As time goes by, some of them pursue entrepreneurial opportunities and become entrepreneurs, which explains why older cohorts show a higher prevalence rate of entrepreneurs. There is supporting evidence that the self-employed people are in average older than the people in the other labor market occupations (Cowling and Taylor, 2001). Coate et al. (1992) explains this with individual human capital accumulation i.e. as individuals gain professional experience and have formed large networks, they can better exploit the opportunities. They also have more probably more capital to invest. Age may predict preference for self-employment because older individuals may be better at judging their self-efficacy.

Lévesque and Minniti (2006) have shown the existence of an inverted U-shaped relationship between age and entrepreneurial behavior. Similar results are reported in Henley (2007). According to Henley (2007) although young 
adults are most likely to state entrepreneurial aspirations it is not until the mid30 s that they have acquired sufficient experience to make the transition into self-employment most likely. Gimeno et al. (1997), instead, have discussed the importance of age in determining an individual's exit costs from entrepreneurship. In their work, age is used to empirically approximate the switching costs faced by an entrepreneur who is considering getting out of the business. Such switching costs are assumed to increase with age.

Age is associated with increased human and social capital. Older individuals have more experience and hence one could assume that they are more persistent in the startup process. Social capital facilitates resource co-optation and acquisition through network contacts (Starr and McMillan, 1990) and therefore is likely to increase the persistence in the startup process. Those with higher levels of social capital were more likely to make the startup process move forward in the study of Davidsson and Honig (2003). Based on the human capital theory and the empirical evidence, our hypothesis is as follows:

Hypothesis 2: At the country level, age is positively related both to a) the ratio of nascent entrepreneurs to potential entrepreneurs and b) the ratio of baby business owners to nascent entrepreneurs.

\subsection{Education}

At the individual-level, education has been expected to be related with the preference for self-employment. Grilo and Irigoyen (2006) and Henley (2007) find that the level of education does not play a role in explaining preferences for self-employment. Furthermore, Davidsson and Honig (2003) argue that human capital alone is not enough to start a new business.

Results on education and likelihood of entrepreneurial activity are mixed. Evans and Leighton $(1989,1990)$ and Arenius and Minniti (2005) conclude that education increases the probability of being self-employed. Lin et al. (2000) do not find evidence of a significant impact of education on entry into selfemployment. Blanchflower et al. (2001) find a negative relationship between education and entrepreneurial activity. Some suggest that the relationship between human capital and entrepreneurial activity may be confounded by a number of factors. Reynolds (1997) results suggest that the effect of education on nascent entrepreneurs is non-linear and subject to cross effects with other variables such as age and gender. For women, education seems to be particularly important (Bates, 1995).

Grilo and Irigoyen (2006) report on a U-shaped relationship between education and entrepreneurial activity. Relative to the intermediate level of education, belonging to the higher or the lower education group has a positive impact on being self-employed. For those with a low level of education, selfemployed is a high utility career choice. According to Davidsson and Honig (2003) individuals with high levels of education may perceive lower risk in entrepreneurship because the labor market will easily re-absorb them if the venture fails. Furthermore, perhaps individuals with higher amounts of human capital have greater self-confidence, enabling them to make a choice toward independent entrepreneurship. Also, highly educated individuals may recognize more and better opportunities. 
Finally, education has been linked with the transition into self-employment. Henley (2007) finds that those who transition into self-employment are more likely to have college-level or other higher education qualifications. Parker and Belghitar (2006) find that relatively well-educated nascent entrepreneurs, especially those with post-high-school degrees, are significantly less likely to quit nascent entrepreneur status within a year, and significantly more likely to start up. Parker and Belghitar (2006) suggest that human capital is more productive within entrepreneurship than outside it, making start-ups more worthwhile pursuing than quitting. Coate et al. (1992) explains this with individual human capital accumulation i.e. as individuals gain professional experience and have formed large networks, they can better exploit the opportunities. They also have more probably more capital to invest. However, Davidsson and Honig (2003) find that education was not related to the number of actual gestation activities taken during the 18-month study period. Hence, highly educated individuals were not more active during the startup phase.

According to the human capital theory, once engaged in the entrepreneurial process, individuals with more or higher quality human capital should have superior ability in successfully exploiting opportunities (Davidsson and Honig, 2003). Those with higher educational attainment may be better informed or better able to judge the potential for success as an entrepreneur. This gives rise to our hypothesis:

Hypothesis 3: At the country level, education is positively related both to a) the ratio of nascent entrepreneurs to potential entrepreneurs and $b$ ) the ratio of baby business owners to nascent entrepreneurs.

\subsection{Gender}

Women participation rates in entrepreneurship are systematically below those of men. In a recent study of 41 countries, men are overall more likely to be involved in entrepreneurial activity, with the exceptions of Japan, Brazil, Thailand and Peru (Allen, Elam, Langowitz and Dean, 2007). Women also have a lower preference for self-employment (Grilo and Irigoyen, 2006; Henley, 2007). Previous studies report on mixed results on the relationship between gender and likelihood of transitioning into entrepreneurship. Henley (2007) finds that women are significantly less likely than men, other things being equal, to transition into self-employment. On the contrary, Parker and Belghitar (2006) find no gender effect on transition into self-employment.

Women have different motivation for self-employment (Carter et al., 2003). Carter et al. (2003) find that Males were more likely to seek financial success and opportunities to create new products or technology than women. The incentives for female self-employment have been seen to be more complex and non-pecuniary than for their male counterparts (see Boden, 1999; Clain, 2000). The non-pecuniary factors are mostly those affecting the working time and place i.e. desire to be independent. Burke et al. (2002) in line with Boden (1999) argue that the family related incentives of self-employment are more important for females than they are for males. Because of the non-pecuniary motives, women may show higher persistence in the startup process. Even if the exploited opportunity turns out to be of less potential than expected, women persist in the 
startup process because they are interested in autonomy and independence, and less about financial gain.

Few studies have investigated the relationship between gender and persistence in the startup process. Rotefoss and Kolvereid (2005) studied three different milestones in the business gestation process, i.e., becoming an aspiring entrepreneur, a nascent entrepreneur and a founder of a fledgling new business. They found that women were underrepresented in both the aspiring and nascent entrepreneurial categories. However, the odds of founding a business were not affected by gender, indicating that women succeed to the same degree as men in founding a business. Similarly, Parker and Belghitar (2006) utilized an econometric analysis of the transition from a nascent entrepreneur to an entrepreneur and concluded that there did not appear to be significant differences in nascent entrepreneur outcomes by gender endowment. Davidsson and Honig (2003) report that women were somewhat less likely to have performed gestation activities than men were.

Studies on women entrepreneurship show that women business owners face higher resource constraints than male business owners. Women and men start and run businesses in different sectors, pursue different business goals and structure their businesses in a different fashion (e.g., Fischer, Reuber and Dyke, 1993; Chaganti and Parasuraman, 1996; Verheul and Thurik, 2001). Women business owners are more likely to be proprietors than their male counterparts, and less likely to be incorporated businesses (Riding and Swift, 1990; Fabowale, Orser and Riding, 1995). In the context of small businesses, Storey (1994) found that organizational form of the business influences availability of capital. Storey found that bank lending is more likely to limited companies than to sole proprietorships or partnerships. The location of the business may also influence the availability of capital. Home-based businesses maybe less successful candidates for bank loans than businesses located outside of the home, because home-based businesses tend to be younger and less profitable (Edwards and Field-Hendrey, 1996). Financial institutions may also see women owners of home-based businesses to operate businesses that are a hobby or an extension of their gendered role as homemaker (Loscocco and Smith-Hunter, 2004), and therefore view them as less attractive customers. Given the empirical evidence, we expect that the resource constraints faced by women extent also to the gestation phase and hence, our hypothesis reads:

Hypothesis 4: At the country level, gender is negatively related both to a) the ratio of nascent entrepreneurs to potential entrepreneurs and b) the ratio of baby business owners to nascent entrepreneurs.

\section{Data}

For this paper, we used data from 35 countries collected during the GEM 2005 research. The following countries are included in our sample: Argentina, Australia, Austria, Belgium, Brazil, Canada, Chile, China, Croatia, Denmark, Finland, France, Germany, Greece, Hungary, Iceland, Ireland, Italy, Jamaica, Japan, Latvia, Mexico, Netherlands, New Zealand, Norway, Singapore, Slovenia, South Africa, Spain, Sweden, Switzerland, Thailand, United Kingdom, United States 
and Venezuela. The strength of the GEM data lies in its unique character, which enables the definition of an individual country entrepreneurial potential value comparable with other countries, thereby enabling international comparisons. The respondents of the GEM survey were asked specific questions with respect to their personal views regarding their own entrepreneurial skills, and whether they believed that there were good opportunities for them to start a business in their region. The GEM survey also provides data on the conception and gestation phases. For more detailed information, please see Reynolds et al. (2005).

\subsection{Dependent variable}

For the purposes of this study, the prevalence rates for the three first stages of the entrepreneurial process were calculated. More precisely, we calculated the prevalence rate of baby business owners, nascent entrepreneurs and potential entrepreneurs. In the GEM study, owner/managers of firms are classified as 'baby business owners' if the entrepreneurs report that they are active as owner-manager of a new firm that has paid waged or salaries for more than three months, but less than 42 months. This measure is used to calculate the prevalence rate of baby business owners in a given country.

To identify individuals in the process of starting a business, respondents were asked: 'Are you, alone or with others, currently trying to start a new business, including any self-employment or selling any goods or services to others?' Those respondents who answered 'yes' were asked two additional questions. These questions were used to separate those who were truly committed to a new venture from those thinking about but not yet committed to it. These questions inquired (1) 'Over the past twelve months, have you done anything to help start a new business, such as looking for equipment or a location, organizing a start-up team, working on a business plan, beginning to save money, or any other activity that would help launch a business?' and (2) 'Will you personally own all, part, or none of this business?' Only those respondents, who answered 'yes' to the first question and 'all' or 'part' to the second question were coded as nascent entrepreneurs.

In order to qualify as potential entrepreneur the respondent could not be a nascent entrepreneur, a baby business owner or an established business owner. In addition, two other requirements had to be met for a respondent to qualify as a potential entrepreneur. The respondents had to perceive entrepreneurial opportunities and sufficient personal skills for entrepreneurship. The perception of entrepreneurial opportunities was measured with the question: 'During the next six months, will there be good opportunities for starting a business in the area where you live?' The responses were coded as a binary variable with 2 indicating a yes response and 1 indicating a no response. Second, the respondents were asked the question: 'Do you have the knowledge, skill and experience required to start a new business?' The responses were coded as a binary variable with 2 indicating a yes response and 1 indicating a no response.

Once the prevalence rates were calculated, we used them to calculate the ratios characterizing the startup process. Our first measure is the ratio of nascent entrepreneur prevalence rate to the potential entrepreneur prevalence rate (Conception ratio). This is an indication of the likelihood of those having the necessary skills and perceiving entrepreneurial opportunities deciding to pursue 
a new business startup. Our second dependent variable is difference between the baby business owner prevalence rate and the nascent entrepreneur prevalence rate (Birth ratio). This is an indication of how many of those engaging in startup activities are likely to success over time.

Table 1 lists the prevalence rates of potential entrepreneurs, nascent entrepreneurs and baby business owners across the 35 countries included in this study. Our two measures of variation in the startup process, conception ratio and birth ratio, are also listed. The average conception ratio (i.e. ratio of nascent entrepreneur prevalence rate to potential entrepreneur prevalence rate) is 0.37 and the birth ratio (i.e. average ratio of baby business owner prevalence rate to nascent entrepreneur prevalence) rate is 0.84 . At any given time, on average, there are more those who could potentially engage in startup activities than those who are seriously trying to start a new business. Also there are more who are serious trying to start a new business than those who are owner-managers of recently started firms.

TABLE 1

PREVALENCE RATES, CONCEPTION RATIO AND BIRTH RATIO ACROSS 35 COUNTRIES

\begin{tabular}{|l|c|c|c|c|c|}
\cline { 2 - 6 } \multicolumn{1}{c|}{} & $\begin{array}{c}\text { Prevalence } \\
\text { rate of } \\
\text { potential } \\
\text { entrepre- } \\
\text { neurs (A) }\end{array}$ & $\begin{array}{c}\text { Prevalence } \\
\text { rate of } \\
\text { nascent en- } \\
\text { trepreneurs } \\
(\mathrm{B})\end{array}$ & $\begin{array}{c}\text { Prevalence } \\
\text { of baby } \\
\text { business } \\
\text { owners (C) }\end{array}$ & $\begin{array}{c}\text { Conception } \\
\text { ratio (B/A) }\end{array}$ & $\begin{array}{c}\text { Birth ratio } \\
\text { (C/B) }\end{array}$ \\
\hline Venezuela $^{\mathrm{a}}$ & 22.2 & 18.8 & 7.5 & 0.85 & 0.40 \\
\hline Thailand $^{\mathrm{a}}$ & 12.2 & 9.7 & 13.1 & 0.80 & 1.35 \\
\hline China $^{\mathrm{a}}$ & 7.6 & 5.6 & 9.4 & 0.74 & 1.68 \\
\hline Greece $^{\mathrm{b}}$ & 8.4 & 5.2 & 1.6 & 0.62 & 0.31 \\
\hline US $^{\mathrm{b}}$ & 14.5 & 8.8 & 5.2 & 0.61 & 0.59 \\
\hline New Zealand $^{\mathrm{b}}$ & 16.5 & 9.4 & 10.0 & 0.57 & 1.06 \\
\hline Singapore $^{\mathrm{b}}$ & 6.8 & 3.9 & 3.7 & 0.57 & 0.95 \\
\hline Italy $^{\mathrm{b}}$ & 5.6 & 2.9 & 2.3 & 0.52 & 0.79 \\
\hline France $^{\mathrm{b}}$ & 9.6 & 4.7 & 0.7 & 0.49 & 0.15 \\
\hline Germany $^{\mathrm{b}}$ & 6.4 & 3.1 & 2.7 & 0.48 & 0.87 \\
\hline Jamaica $^{\mathrm{a}}$ & 22.0 & 10.5 & 6.7 & 0.48 & 0.64 \\
\hline Hungary $^{\mathrm{a}}$ & 2.4 & 1.1 & 0.8 & 0.46 & 0.73 \\
\hline Latvia $^{\mathrm{a}}$ & 9.3 & 4.2 & 2.7 & 0.45 & 0.64 \\
\hline Iceland $^{\mathrm{b}}$ & 22.8 & 8.5 & 2.7 & 0.37 & 0.32 \\
\hline Australia $^{\mathrm{b}}$ & 18.2 & 6.5 & 4.7 & 0.36 & 0.72 \\
\hline Canada $^{\mathrm{b}}$ & 18.2 & 6.6 & 3.6 & 0.36 & 0.55 \\
\hline Norway $^{\mathrm{b}}$ & 13.7 & 4.4 & 5.2 & 0.32 & 1.18 \\
\hline Ireland $^{\mathrm{b}}$ & 18.9 & 5.7 & 4.7 & 0.30 & 0.82 \\
\hline Finland $^{\mathrm{b}}$ & 10.4 & 3.1 & 1.9 & 0.30 & 0.61 \\
\hline
\end{tabular}




\begin{tabular}{|l|c|c|c|c|c|}
\cline { 2 - 6 } \multicolumn{1}{c|}{} & $\begin{array}{c}\text { Prevalence } \\
\text { rate of } \\
\text { potential } \\
\text { entrepre- } \\
\text { neurs (A) }\end{array}$ & $\begin{array}{c}\text { Prevalence } \\
\text { rate of } \\
\text { nascent en- } \\
\text { trepreneurs } \\
\text { (B) }\end{array}$ & $\begin{array}{c}\text { Prevalence } \\
\text { of baby } \\
\text { business } \\
\text { owners (C) }\end{array}$ & $\begin{array}{c}\text { Conception } \\
\text { ratio (B/A) }\end{array}$ & $\begin{array}{c}\text { Birth ratio } \\
\text { (C/B) }\end{array}$ \\
\hline Slovenia $^{\mathrm{a}}$ & 9.9 & 3.0 & 1.4 & 0.30 & 0.47 \\
\hline Argentina $^{\mathrm{a}}$ & 22.2 & 5.9 & 3.9 & 0.27 & 0.66 \\
\hline Austria $^{\mathrm{b}}$ & 12.5 & 3.0 & 2.4 & 0.24 & 0.80 \\
\hline Japan $^{\mathrm{b}}$ & 4.7 & 1.1 & 1.1 & 0.23 & 1.00 \\
\hline Chile $^{\mathrm{a}}$ & 26.3 & 6.0 & 5.3 & 0.23 & 0.88 \\
\hline UK $^{\mathrm{b}}$ & 16.4 & 3.4 & 2.9 & 0.21 & 0.85 \\
\hline Croatia $^{\mathrm{a}}$ & 19.9 & 4.1 & 2.5 & 0.21 & 0.61 \\
\hline South Africa $^{\mathrm{a}}$ & 16.8 & 3.6 & 1.7 & 0.21 & 0.47 \\
\hline Mexico $^{\mathrm{a}}$ & 22.4 & 4.6 & 1.4 & 0.21 & 0.30 \\
\hline Switzerland $^{\mathrm{b}}$ & 13.3 & 2.6 & 3.7 & 0.20 & 1.42 \\
\hline Brazil $^{\mathrm{a}}$ & 17.4 & 3.3 & 8.2 & 0.19 & 2.48 \\
\hline Spain $^{\mathrm{b}}$ & 12.7 & 2.4 & 3.4 & 0.19 & 1.42 \\
\hline Netherlands $^{\mathrm{b}}$ & 13.3 & 2.5 & 1.9 & 0.19 & 0.76 \\
\hline Denmark $^{\mathrm{b}}$ & 21.2 & 2.4 & 2.4 & 0.11 & 1.00 \\
\hline Belgium $^{\mathrm{b}}$ & 26.3 & 2.9 & 1.2 & 0.11 & 0.41 \\
\hline Sweden $^{\mathrm{b}}$ & 19.7 & 1.7 & 2.5 & 0.09 & 1.47 \\
\hline Average & 14.9 & 5.0 & 3.9 & 0.37 & 0.84 \\
\hline
\end{tabular}

a A developing country with the GPD per capita in 2005 less than USD 20,000.

b A developed country with the GDP per capita in 2005 more than USD 20,000.

To examine the country differences, we group the countries into 'high' and 'low' value countries; 'high' value countries having a ratio above the group mean and 'low' value countries having a ration below the group mean. The independent samples $\mathrm{T}$ test showed that there are significant differences between countries in the entrepreneurial process (Table 2). Countries with above the mean conception ratios differed statistically significantly from the below the mean countries. The same applied to the next phase of becoming an entrepreneur, "from a nascent entrepreneur to a baby business owner". Countries with above the mean birth ratios differed statistically significantly from the below the mean countries.

The $\mathrm{T}$ tests prove that the likelihood of success in the entrepreneurial startup process varies across countries. In some countries more people make the transition from the previous phase to the next and progress in the entrepreneurial startup process. In other countries individuals are more likely to exit the entrepreneurial process. 
TABLE 2

CONCEPTION RATIO AND BIRTH RATIO BY COUNTRY

\begin{tabular}{|c|c|c|c|c|c|c|}
\hline & $\begin{array}{l}\text { Country } \\
\text { grouping }\end{array}$ & $\mathrm{N}$ & Mean & $\begin{array}{c}\text { Std } \\
\text { deviation }\end{array}$ & $\mathrm{T}$ & Sig. \\
\hline \multicolumn{7}{|c|}{ Country comparison (Independent sample T Test) } \\
\hline \multirow{2}{*}{$\begin{array}{l}\text { Conception } \\
\text { ratio }\end{array}$} & High & 13 & 0.588 & 0.133 & \multirow{2}{*}{-9.829} & \multirow{2}{*}{$0.000^{* * *}$} \\
\hline & Low & 22 & 0.236 & 0.080 & & \\
\hline \multirow{2}{*}{ Birth ratio } & High & 14 & 1.258 & 0.439 & \multirow{2}{*}{-6.467} & \multirow{2}{*}{$0.000^{* * *}$} \\
\hline & Low & 21 & 0.560 & 0.190 & & \\
\hline
\end{tabular}

$* * *$ significant at $\mathrm{p} \leq 0.001 ; * *$ significant at $\mathrm{p} \leq 0.01 ; *$ significant at $\mathrm{p} \leq 0.05$.

\subsection{Independent variables}

In order to examine the influence of culture, we based our study on Geert Hofstede's original study Culture's Consequences. Comparing Values, Behaviors, Institutions and Organizations across Nations. We selected individualism-collectivism, masculinity-femininity and last, power distance value. In Hofstede's study, these dimensions are measured on an index from 0 to 100. For instance, a high score in individualism is near a 100 index value and a low index value near zero. Croatia, Iceland, Latvia and Slovenia were not included in Hofstede's study and are thus left out of the analysis when cultural variables are concerned. Based on Hofstede's results, we categorized the remaining 31 countries into high and low scoring countries on each of the three dimensions. ${ }^{1}$ For both groups we calculated the conception ratio (i.e. ratio of nascent entrepreneur prevalence rate to potential entrepreneur prevalence rate) and the birth ratio (i.e. ratio of baby business owner prevalence rate to nascent entrepreneur prevalence rate). Hence, we were able to compare high and low scoring countries on our measures of persistence.

In order to examine the differences across gender, age and educational background, we carried out the following. First, we split the sample into men and women, and calculated for both groups the conception and birth ratios. For education, we split the respondents into three groups: people with a maximum of a secondary education, people with post-secondary education and people with graduate experience. For each three groups, we calculated the respective ratios. Similarly, for age, we divided the respondents into three categories: 18-24, 25-44 and 45-64 of age and again, calculated the respective ratios.

\footnotetext{
1 The exact data available at http://www.geert-hofstede.com/hofstede_dimensions.php
} 


\section{Results}

Two analysis methods were used in this study. First, we utilized individual samples $\mathrm{T}$ test on countries and cultural variables of individualism, masculinity and power distance. Paired samples T tests were utilized when analyzing gender differences. Second, ANOVA testing was used to assess the differences between the age and education groups. Next we will report the results of hypothesis testing.

The independent samples T tests utilized showed that there were no statistically significant differences between countries with regard to country groupings of high or low cultural values of 'individualism-collectivism', 'power distance' and 'masculinity-femininity' (Table 3). Hence, hypothesis 1 is not supported in our data. Countries scoring high on 'individualism-collectivism' had lower conception ratios than did countries scoring low on individualism. The difference of the means is however not significant. Similarly, countries scoring high on 'individualism-collectivism' had lower birth ratios than did countries scoring low on individualism. The difference of the means is however again not significant. Countries scoring high on the 'masculinity-femininity' dimension had higher conception ratios than did countries scoring low on 'masculinity-femininity'. The difference of the means is again not significant. Furthermore, countries scoring high on 'masculinity-femininity' dimension had lower birth ratios than did countries scoring low on 'masculinity-femininity'. The difference of the means is weakly significant. Countries scoring high on 'power distance' had higher conception ratios than did countries scoring low on 'power distance'. The difference of the means is however not significant. Similarly, countries scoring high on 'power distance' had higher birth ratios than did countries scoring low on 'power distance'. The difference of the means is however not significant.

Hypothesis 2 was partially supported. A one-way analysis of variance revealed that the conception ratio differed significantly as a function of age. The means and standard deviations are presented in Table 4. Posthoc testing using the Tukey B test showed that the age groups ' 18 to 24 years' and '25 to 44 years' differ significantly. In regard to birth ratio, a one-way analysis of variance yielded no significant results.

Hypothesis 3 was not supported on our data. In regard to education, a oneway analysis of variance did not reveal any significant differences between groups. Similarly no between group differences were found in regard to birth ratio. Table 4 reports the means and standard deviations.

The paired samples $\mathrm{T}$ test showed that there are gender-related differences in the entrepreneurial process (Table 5). Men had a higher conception ratio compared to women. This difference is significant. Of potential entrepreneurs, more men than women engage in entrepreneurial activity. In regard to the birth ratio, women had a higher ratio compared to men. The difference is however not significant. 
TABLE 3

CONCEPTION RATIO AND BIRTH RATIO BY NATIONAL CULTURE

\begin{tabular}{|c|c|c|c|c|c|c|}
\hline & $\begin{array}{c}\text { Country } \\
\text { grou- } \\
\text { ping }\end{array}$ & $\mathrm{N}$ & Mean & $\begin{array}{c}\text { Std } \\
\text { devia- } \\
\text { tion }\end{array}$ & $\mathrm{T}$ & Sig. \\
\hline \multicolumn{7}{|c|}{ Culture: Individualism (Independent sample T Test) } \\
\hline \multirow{2}{*}{ Conception ratio } & High & 18 & 0.327 & 0.165 & \multirow{2}{*}{-1.400} & \multirow{2}{*}{0.172} \\
\hline & Low & 13 & 0.432 & 0.254 & & \\
\hline \multirow{2}{*}{ Birth ratio } & High & 18 & 0.803 & 0.337 & \multirow{2}{*}{-1.086} & \multirow{2}{*}{0.287} \\
\hline & Low & 13 & 0.990 & 0.618 & & \\
\hline \multicolumn{7}{|c|}{ Culture: Masculinity (Independent sample T Test) } \\
\hline \multirow{2}{*}{ Conception ratio } & High & 19 & 0.404 & 0.209 & \multirow{2}{*}{1.087} & \multirow{2}{*}{0.286} \\
\hline & Low & 12 & 0.320 & 0.209 & & \\
\hline \multirow{2}{*}{ Birth ratio } & High & 19 & 0.764 & 0.354 & \multirow{2}{*}{-1.788} & \multirow{2}{*}{0.084} \\
\hline & Low & 12 & 1.067 & 0.591 & & \\
\hline \multicolumn{7}{|c|}{ Culture: Power Distance (Independent sample T Test) } \\
\hline \multirow{2}{*}{ Conception ratio (NB!) } & High & 15 & 0.415 & 0.253 & \multirow{2}{*}{1.122} & \multirow{2}{*}{0.273} \\
\hline & Low & 15 & 0.330 & 0.156 & & \\
\hline \multirow{2}{*}{ Birth ratio } & High & 15 & 0.883 & 0.633 & \multirow{2}{*}{0.023} & \multirow{2}{*}{0.982} \\
\hline & Low & 15 & 0.789 & 0.879 & & \\
\hline
\end{tabular}

*** significant at $\mathrm{p} \leq 0.001 ; * *$ significant at $\mathrm{p} \leq 0.01$; * significant at $\mathrm{p} \leq 0.05$.

(NB!) Equal variances not assumed.

TABLE 4

CONCEPTION RATIO AND BIRTH RATIO BY EDUCATION AND AGE

\begin{tabular}{|c|c|c|c|c|c|c|}
\hline & & $\mathrm{N}$ & Mean & $\begin{array}{c}\text { Std } \\
\text { devia- } \\
\text { tion }\end{array}$ & $\mathrm{F}$ & Sig. \\
\hline \multicolumn{7}{|l|}{ Age } \\
\hline \multirow{3}{*}{ Conception ratio } & $18-24$ & 34 & 0.302 & 0.222 & \multirow{3}{*}{3.786} & \multirow{3}{*}{$0.026^{*}$} \\
\hline & $25-44$ & 34 & 0.487 & 0.348 & & \\
\hline & $45-64$ & 34 & 0.346 & 0.288 & & \\
\hline \multirow{3}{*}{ Birth ratio } & $18-24$ & 34 & 1.025 & 0.751 & \multirow{3}{*}{0.753} & \multirow{3}{*}{0.474} \\
\hline & $25-44$ & 34 & 0.848 & 0.446 & & \\
\hline & $45-64$ & 34 & 0.903 & 0.584 & & \\
\hline
\end{tabular}




\begin{tabular}{|c|c|c|c|c|c|c|}
\hline & & $\mathrm{N}$ & Mean & $\begin{array}{c}\text { Std } \\
\text { devia- } \\
\text { tion }\end{array}$ & $\mathrm{F}$ & Sig. \\
\hline \multicolumn{7}{|l|}{ Education } \\
\hline \multirow{3}{*}{ Conception ratio } & Secondary education & 28 & 0.381 & 0.283 & \multirow{3}{*}{0.456} & \multirow{3}{*}{0.635} \\
\hline & Post-secondary education & 28 & 0.451 & 0.351 & & \\
\hline & Graduate experience & 28 & 0.450 & 0.308 & & \\
\hline \multirow{3}{*}{ Birth ratio } & Secondary education & 28 & 0.918 & 0.574 & \multirow{3}{*}{0.269} & \multirow{3}{*}{0.765} \\
\hline & Post-secondary education & 28 & 0.956 & 0.515 & & \\
\hline & Graduate experience & 28 & 0.855 & 0.460 & & \\
\hline
\end{tabular}

$* * *$ significant at $\mathrm{p} \leq 0.001 ; * *$ significant at $\mathrm{p} \leq 0.01 ; *$ significant at $\mathrm{p} \leq 0.05$.

TABLE 5

CONCEPTION RATIO AND BIRTH RATIO BY GENDER

\begin{tabular}{|l|c|c|c|c|c|c|}
\cline { 2 - 7 } \multicolumn{1}{c|}{} & $\begin{array}{c}\text { Country } \\
\text { group- } \\
\text { ing }\end{array}$ & $\mathrm{N}$ & Mean & $\begin{array}{c}\text { Std de- } \\
\text { viation }\end{array}$ & $\mathrm{T}$ & Sig. \\
\hline Gender (Paired sample T test) \\
\hline Conception ratio & & 35 & -1.740 & 3.474 & -2.963 & $0.006^{* *}$ \\
\hline Birth ratio & & 35 & -0.806 & 2.482 & -1.921 & 0.063 \\
\hline
\end{tabular}

$* * *$ significant at $\mathrm{p} \leq 0.001 ; * *$ significant at $\mathrm{p} \leq 0.01 ; *$ significant at $\mathrm{p} \leq 0.05$.

\section{Discussion}

This paper examined the entrepreneurial startup process and the level of activity in the different stages of the startup process. Particularly, the study has concentrated on the two transitions of becoming an entrepreneur. These transitions are from potential to nascent entrepreneur and from nascent entrepreneurs to a baby business owner. Using the GEM data, we were able to explore two measures of the entrepreneurial startup process: (1) the birth ratio (i.e. the ratio of the baby business owner prevalence rate and the nascent entrepreneur prevalence rate) and (2) the conception ratio (i.e. the ratio of the nascent entrepreneur prevalence rate and potential entrepreneur prevalence rate).

This study has shown that at any given time there are entrepreneurs in every stage of the entrepreneurial startup process and that there are differences between the stages in respect to the prevalence rates. The prevalence rates decrease as we move closer to the actual startup in the entrepreneurial process. Overall the transition from nascent entrepreneur to baby business owner is likelier than the transition from potential entrepreneur to nascent entrepreneur. There are both developed and developing countries in which the difference in the level of nascent entrepreneur and potential entrepreneurs is large. For example, Sweden, 
Denmark and Belgium have a much higher potential entrepreneur prevalence rate than nascent entrepreneur prevalence rate. Similarly, of the developing countries Chile, Mexico and Argentina show similar results. On the other hand, Thailand, China, Italy and Hungary have very little difference in the prevalence rates before-and-after gestation transition point. In this study, we explored culture as a factor underlying the country-level differences.

However, cultural variables of 'individualism-collectivism', 'power distance' and 'masculinity-femininity' do not appear to be related with the differences of the prevalence rates. Especially individualism has been noted in several studies as an important explaining factor for entrepreneurship. Although otherwise quite useful as an explaining factor for entrepreneurship, it appears that individualism does not matter when transitions in the entrepreneurial process are studied. The only result we found was that those countries, which score low on the 'masculinity-femininity' dimension, have somewhat higher birth rates.

We also find more differences related to the transition from potential entrepreneur to nascent entrepreneur than related to the transition from nascent entrepreneur to baby business owner. Our results show that gender is related to the ratio of nascent entrepreneur to potential entrepreneurs. We find that the ratio of nascent to potential entrepreneurs is higher for men than for women. Similar results were reported in Henley (2007). In the subsequent transition the difference is statistically not significant Suggesting that once engaged in startup activities, women and men are equally likely to succeed in creating a viable venture. Here our results support the finding of Parker and Belghitar (2006). Of the socio-economic factor also age is significant in our study. We find that the middle-aged adults show a higher ratio of nascent entrepreneurs to potential entrepreneurs than young adults. Interestingly there are no age related differences in regard to the transition from nascent entrepreneur to baby business owner.

Because of the complex nature of the process, we are very cautious about presenting policy recommendations based on our study. Nevertheless, our conclusions side with those of Rotefoss and Kolvereid (2005). They suggested that initiatives supporting entrepreneurship among women should be directed towards stimulating entrepreneurial intentions and triggering start-up attempts. However in terms of succeeding in the entrepreneurial start-up process and creating a lasting organization, this could have negative implications. It is possible that with the increasing number of attempts the success rate declines, because less qualified and less motivated women engage in the startup process.

Certain limitations of this study are to be noted. First, the GEM data used represents a snapshot of the situation in 2005. For a more accurate study, longer time periods over several years should be used. Our study has look at the entrepreneurial startup process at the population level. Studies which track individuals over time such as Parker and Belghitar (2006), Henley (2007), Rotefoss and Kolvereid (2005), Kolvereid and Isaksen (2006) and Alsos and Kolvereid (1999) provide more detailed information on which personal, social and economic factors are associated with remaining in one stage or transition to the next one, or alternatively exiting the entrepreneurial startup process altogether. Second, the part of data which is used to identify potential entrepreneurs is based on people's personal perceptions rather than their actual prerequisites for entrepreneurship or concrete entrepreneurial activity. This obviously sets some limitations for the interpretation of the data. 
The findings seem to suggest that future research should pay more attention to the earlier stages of the process and not focus solely on the end results of the process, i.e., the established business owners. More and better information regarding the factors influencing the entrepreneurial process is still lacking and we have only scratched the surface with our paper. Knowing more about the process and the factors influencing transitions between the phases offers valuable information for policymakers trying to build more support structures for people to become entrepreneurs.

\section{REFERENCES}

Aldrich, H. E. \& Argelia Martínez, M. (2001). "Many are Called but Few are Chosen: An Evolutionary Perspective for the Study of Entrepreneurship". Entrepreneurship Theory and Practice, 4, 41-56.

Allen, I. E.; Langowitz, N. \& Minniti, M. (2007). Global Entrepreneurship Monitor. 2006 Report on Women and Entreprenurship. London, UK: London Business School-Babson Park, MA.: Babson College.

Alsos, G. A. \& Kolvereid, L. (1998). "The business gestation process of novice, serial, and parallel business founders". Entrepreneurship Theory and Practice, 22, 101-114.

Arenius, P. \& Minniti, M. (2005). "Perceptual variables and nascent entrepreneurship". Small Business Economics, 24, 233-247.

Bates, T. (1995). "Self-employment entry across industry groups". Journal of Business Venturing 10, 143-156.

Blanchflower, D.G.; Oswald, A. \& Stutzer, A. (2001). "Latent Entrepreneurship across nations". European Economic Review, 45, 680-691.

Boden, R. J. Jr. (1999). "Gender inequality in wage earnings and female selfemployment selection”. Journal of Socio-Economics, 28, 351-364.

Bosma, N. \& Harding, R. (2006). Global Entrepreneurship. GEM 2006, Summary Results, London, UK: London Business School-Babson Park, MA.: Babson College.

Bosma, N. \& Schutjens, V. (2007, February). Mapping Entrepreneurial Activity and Entrepreneurial Attitudes in European Regions. (Paper presented at the $5^{\text {th }}$ IECER Conference 2007, Montpellier).

Brush, C. G. (1990). "Women and enterprise creation: Barriers and opportunities". In Enterprising Women: Local initiatives for job creation. Gould, S. and J. Parzen eds. OECD, Paris.

Brush, C. G. (1992). "Research on women business owners: Past trends, a new perspective and future directions". Entrepreneurship Theory and Practice 16, 5-30.

Burke, A. E.; Fitz Roy, F. R.; Nolan, M. A. (2002). "Self-employment wealth and job creation: the roles of gender, non pecuniary motivation and entrepreneurial ability". Small Business Economics, 19: 255-270.

Carr, D. (1996). "Two paths to self-employment". Work and Occupations 23, 26-52.

Carter, N.; Gartner, W. \& Reynolds, P. (1996). "Exploring the start-up event sequences". Journal of Business Venturing, 11, 151-166. 
Carter, N. M.; Gartner, W. B.; Shaver, K. G. \& Gatewood, E. J. (2003). "The Career Reasons of Nascent Entrepreneurs". Journal of Business Venturing, 13-39.

Chaganti, R. \& Parasuraman, S. (1996). "A study of the impacts of gender on business performance and management patterns in small businesses". Entrepreneurship: Theory and Practice, Winter 1996, 73-75.

Clain, S. H. (2000). "Gender differences in full-time self-employment". Journal of Economics and Business, 52, 499-513.

Coate, S. \& Tennyson, S. (1992). "Labor market discrimination, imperfect information, and self-employment". Oxford Economic Papers, New Series, 44, 2: 272-288.

Cowling, M. \& Taylor, M. (2001). "Entrepreneurial Women and Men: Two Different Species?". Small Business Economics, 16, 167-175.

Davidsson, P. \& Honig, B. (2003). "The role of social and human capital among nascent entrepreneurs". Journal of Business Venturing, 18, 301-331.

Delmar, F. \& Davidsson, P. (2000). "Where Do They Come From? Prevalence and Characteristics of Nascent Entrepreneurs". Entrepreneurship \& Regional Development, 12, 1-23.

Edwards, L. \& Field-Hendrey, E. (1996). "Home-based workers: data from the 1990 Census of Population". Monthly Labour Review, 119 (11), 26-34.

Evans, D. S. \& Leighton, L.S. (1989). "Some empirical aspects of entrepreneurship". American Economic Review, 79, 519-535.

Evans, D. S. \& Leighton, L. S. (1990). "Small business formation by unemployed and employed workers". Small Business Economics, 2, 319-330.

Fabowale, L.; Orser, B. \& Riding, A. (1995). "Gender, structural factors, and credit terms between Canadian small businesses and financial institutions". Entrepreneurship: Theory and Practice, 19, 41-65.

Fischer, E. M.; Reuber, A. R. \& Dyke, L. S. (1993). "A theoretical overview and extension of research on sex, gender and entrepreneurship". Journal of Business Venturing 8, 151-168.

Gatewood, E. J.; Shaver, K. G. \& Gartner, W. B. (1995). “A Longitudinal Study of Cognitive Factors Influencing Start-Up Behaviors and Success at Venture Creation". Journal of Business Venturing, 371-391.

George, G.; Zahra, S. A. (2002). "Culture and Its Consequence for Entrepreneurship". Entrepreneurship Theory and Practice, summer, 4, 5-8.

Gimeno, J.; Folta, T.; Cooper, A. \& Woo, C. (1997). "Survival of the fittest? Entrepeneurial human capital and the persistence of underperforming firms". Administrative Science Quarterly, 42, 750-783.

Greene, P. (2000). "Self-Employment as an economic behavior: An analysis of self-employed women's human and social capital". National Journal of Sociology. 12, 1-55.

Grilo, I. \& Irigoyen, J.-M. (2006). "Entrepreneurship in the EU: To wish and not to be". Small Business Economics, 26, 305-318.

Hair, J. F.; Anderson, R. E.; Tatham, R. L. \& Black, W. C. (1998). Multivariate Data Analysis. (New Jersey: Prentice Hall).

Hayton J.C.; George, G. \& Zahra, S.A. (2002). "National Culture and Entrepreneurship: A Review of Behavioural Research". Entrepreneurship Theory and Practice, summer, 26, 33-52. 
Henley, A. (2007). "Entrepreneurial aspiration and transition into self-employment: evidence from British longitudinal data". Entrepreneurship \& Regional Development, 19: 3, 253-280.

Hisrich, R. D. \& Brush, C. G. (1985). "Women and minority entrepreneurs: A comparative analysis". Frontiers of Entrepreneurship Research. Babson Press, Babson Park, MA.

Hisrich, R. D. \& Brush, C. G. (1984). "The woman entrepreneur: Management skills and business problems". Journal of Small Business Management, 22, 31-37.

Hofstede, G. (2001). Culture's Consequences. Comparing Values, Behaviors, Institutions and Organizations Across Nations. (Thousand Oaks: Sage).

Inglehart, R. \& Baker, W. E. (2000). "Modernization, Cultural Change, and the Persistence of Traditional Values". American Sociological Review, 65, 19-51.

Kolvereid, L. \& Isaksen, E. (2006). "New business startup and subsequent entry into self-employment". Journal of Business Venturing, 21, 566-885.

Lee, S. \& Peterson, S. (2000). "Culture, Entrepreneurial Orientation, and Global Competiveness". Journal of World Business, 35, 401-416.

Lévesque, M.; Minniti, M. (2006). "The Effect of Aging on Entrepreneurial Behavior". Journal of Business Venturing, 21, 177-194.

Levie, J. \& Hunt, S. (2004). “Culture, Institutions, and New Business Activity: Evidence from Global Entrepreneurship Monitor". Frontiers of Entrepreneurship Research. Babson Press, Babson Park, MA. (Working paper).

Lin, Z.; Picot, G. \& Compton, J. (2000). "The entry and exit dynamics of selfemployment in Canada". Small Business Economics, 15 (2), 105-125.

Ljunggren, E. \& Kolvereid, L. (1996). "New Business Formation: Does Gender Make a Difference?". Women in Management Review, 4, 3-12.

Lombard, K. (2001). "Female self-employment and demand for flexible, nonstandard work schedules". Economic Inquiry, 39, 214-237.

Loscocco, K. \& Smith-Hunter, A. (2004). "Women home-based business owners: insights from comparative analysis". Women in Management Review, 19(3), 164-173.

Lundström, A. \& Stevenson, L. A. (2005). Entrepreneurship Policy. Theory and Practice. (New York: Springer).

McGrath, R.; McMillan, J.; Yang, E. \& Tsai, W. (1992). "Does culture endure, or is it malleable? Issues for entrepreneurial economic development". Journal of Business Venturing, 7, 441-458.

Minniti, M.; Bygrave, W. D. \& Autio, E. (2006). GEM, Global Entrepreneurship Monitor, 2005, Executive Report, London, UK: London Business SchoolBabson Park, MA.: Babson College.

Mueller, S. \& Thomas, A. (2000). "Culture and entrepreneurial potential: A nine country study of locus of control and innovativeness". Journal of Business Venturing, 16, 51-75.

Noorderhaven, N.; Thurik, R.; Wennekers, S. \& van Stel, A. (2004). "The Role of dissatisfaction and per capita income in explaining self-employment across 15 European countries". Entrepreneurship Theory \& Practice, $28,447-466$. 
Parker, S. \& Belghitar, Y. (2006). "What Happens to Nascent Entrepreneurs? An Econometric Analysis of the PSED". Small Business Economics, 27, 81-101.

Pinillos-Costa, M.-J.; Reyes-Recio, L.-E. \& Pinar, I. (2007). Inferences from an Individualist-Collectivist Culture on Entrepreneurship: Evidence from GEM data. (Paper presented at the ICSB Conference 2007, Turku).

Reynolds, P. \& White, S. B. (1997). The Entrepreneurial Process. Economic Growth, Men, Women and Minorities. (Westport: Quorom).

Reynolds, P.; Bosma, N.; Autio, E.; Hunt, S.; De Bono, N.; Servais, I.; LopezGarcia, P. \& Chin, N. (2005). "Global Entrepreneurship Monitor: Data Collection Design and Implementation”. Small Business Economics, 24, 205-231.

Reynolds, P.; Carter, N.; Gartner, W.; Greene, P. (2004). “The prevalence of nascent entrepreneurs in the United States: Evidence from the panel study of entrepreneurial dynamics". Small Business Economics, 23, 263-284.

Reynolds, P.; Storey, D. J. \& Westhead, P. (1994). “Cross-national Comparisons of the Variation in New Firm Formation Rates". Regional Studies, 28, 443-456.

Riding, A. L. \& Swift, C. S. (1990). "Women business owners and the terms of credit: Some empirical findings of the Canadian experience". Journal of Business Venturing, 5, 327-340.

Rotefoss, B. \& Kolvereid, L. (2005). “Aspiring, Nascent and Fledling Entrepreneurs: An Investigation of the Start-Up Process". Entrepreneurship \& Regional Development, 109-127.

Shane, S. (1992). "Why do some societies invent more than others?". Journal of Business Venturing, 7, 29-46.

Starr, J. A. \& McMillan, I. C. (1990). "Resource cooptation via social contracting: resource acquisition strategies for new ventures". Strategic Management Journal, 11, 79-92.

Storey, D. (1994). "New firm growth and bank financing". Small Business Economics, 6, 139-150.

Thurik, R. \& Verheul, I. (2001). “Start-up capital: Does gender matter?”. Small Business Economics, 16, 329-345.

Tiessen, J. H. (1997). "Individualism, Collectivism, and Entrepreneurship: A Framework for International Comparative Research". Journal of Business Venturing, 12, 367-384.

Uhlaner, L. \& Thurik, R. (2007). "Postmaterialism influencing total entrepreneurial activity across nations". Journal of Evolutionary Economics, 17, 161-185.

Verheul, I. \& Thurik, R. A. (2001). "Start-up capital: Does gender matter?”. Small Business Economics, 16, pp. 329-345.

Wennekers, S.; Thurik, R.; van Stel, A. \& Noorderhaven, N. (2004). "Uncertainty avoidance and the rate of business ownership across 21 OECD countries, 1976-2004". Journal of Evolutionary economics, 17, 133-160. 